\title{
HUBUNGAN BEBAN KERJA PERAWAT DENGAN UPAYA PENCEGAHAN HAIS PADA MASA PANDEMI COVID 19 DI RUMAH SAKIT PERTAMINA BINTANG AMIN BANDAR LAMPUNG
}

\section{Triyoso $^{1}$, Dewi Kusumaningsih ${ }^{2 *}$, Respa Agustina Anggara ${ }^{3}$}

\author{
${ }^{1}$ Dosen Program Studi Ilmu Keperawatan Universitas Malahayati \\ E-mail : triyosoalip@gmail.com \\ ${ }^{2}$ Dosen Program Studi IImu Keperawatan Universitas Malahayati \\ E-mail : dewikusumaningsih@gmail.com \\ ${ }^{3}$ Mahasiswi PSIK Universitas MalahayatI Bandar Lampung \\ E-mail : respamalahayati2017@gmail.com
}

Disubmit: 18 September 2021 Diterima: 30 Desember $2021 \quad$ Diterbitkan: 01 Januari 2022 DOI: https://doi.org/10.33024/mnj.v1i1.5150

\section{ABSTRACT: RELATIONSHIP OF NURSES WORKLOAD WITH HAIS PREVENTION EFFORT DURING THE COVID-19 PANDEMIC AT PERTAMINA BINTANG AMIN HOSPITAL BANDAR LAMPUNG}

Introduction: The incidence of menstruation is still high, one of the factors is the relatively high workload of nurses.excessive workload on nurses can trigger stress and burnout. Nurses who experience stress and burnout allow them to not be able to perform effectively and efficiently because their physical and cognitive abilities are reduced which may occur due to an imbalance between the number of patients and the number of nurses working in the hospital. Based on the results of the pre-survey, the comparison of the workload of nurses at Pertamina Bintang Amin Hospital Bandar Lampung and dr. A. Dadi Tjokrodipo by distributing questionnaires to 15 nurses in each hospital. At the hospital. Pertamina Bintang Amin showed that nurses experienced a physical workload of 7 nurses (46.6\%) with a score of 27-54, and a mental workload of 8 nurses (53.3\%) with a score of $>57$. Meanwhile, RSUD dr. A. Dadi Tjokrodipo, the results showed that nurses experienced a physical workload of 5 nurses (33.3\%) with a score of 27-54, and a mental workload of 6 nurses (40\%) with a score of $>57$.

Objective: to find out the relationship between the workload of nurses and efforts to prevent HAls during the Covid 19 pandemic at Pertamina Bintang Amin Hospital Bandar Lampung in 2021

Methods: This type of research is quantitative, cross sectional design. The population and sample were 110.1 respondents, which were rounded up to 111 respondents. The sampling technique was purposive sampling, data analysis using univariate and bivariate using chi square test.

Results: The physical workload of nurses as many as 57 respondents (51.4\%) experienced a high physical workload. The mental workload of nurses as many as 61 respondents (55.0\%) experienced a high mental workload. Efforts to prevent HAls during the Covid 19 pandemic were 64 respondents (57.7\%) with bad HAls prevention. The results of the analysis using chi-square, obtained $P$ Value $=0.000$ so that $P$-Value $<a(0.000<0.05)$, it can be concluded that there is a relationship between the physical workload of nurses and efforts to prevent HAls during the covid 19 pandemic. The results of the analysis using chi- square, obtained $P$-Value $=0.015$ so that $P$-Value $<a(0.000<0.05)$, it can 
be concluded that there is a relationship between the physical mental workload of nurses and efforts to prevent HAls during the covid 19 pandemic.

Suggestion: Hospitals as a place for health services should pay attention to the welfare of nurses by increasing the medical team, and paying attention to BOR to prevent physical and mental workloads.

Keywords: Nurse Workload, Efforts to Prevent Menstruation, Covid 19 Pandemic

\section{INTISARI: HUBUNGAN BEBAN KERJA PERAWAT DENGAN UPAYA PENCEGAHAN HAIS PADA MASA PANDEMI COVID 19 DI RUMAH SAKIT PERTAMINA BINTANG AMIN BANDAR LAMPUNG}

Pendahuluan: Angka kejadian hais masih tinggi salah satu faktor nya adalah beban kerja perawat yang relatif tinggi. Beban kerja yang berlebih pada perawat dapat memicu timbulnya stres dan burnout. Perawat yang mengalami stres dan burnout memungkinkan mereka untuk tidak dapat menampilkan performa secara efektif dan efisien dikarenakan kemampuan fisik dan kognitif mereka menjadi berkurang yang kemungkinan dapat terjadi disebabkan karena ketidakseimbangan antara jumlah pasien dengan jumlah perawat yang bekerja di rumah sakit tersebut.Berdasarkan hasil Prasurvey perbandingan beban kerja perawat di Rumah Sakit Pertamina Bintang Amin Bandar Lampung dan RSUD dr. A. Dadi Tjokrodipo dengan cara melakukan penyebaran kuesioner kepada 15 perawat di masing-masing Rumah Sakit. Pada RS. Pertamina Bintang Amin diperoleh hasil perawat mengalami beban kerja fisik sebesar 7 perawat $(46,6 \%)$ dengan skor nilai $27-54$, dan beban kerja mental sebesar 8 perawat $(53,3 \%)$ dengan skor nilai > 57. Sedangkan RSUD dr. A. Dadi Tjokrodipo diperoleh hasil perawat mengalami beban kerja fisik sebesar 5 perawat $(33,3 \%)$ dengan skor nilai 27-54, dan beban kerja mental sebesar 6 perawat (40\%) dengan skor nilai > 57.

Tujuan: diketahui hubungan beban kerja perawat dengan upaya pencegahan HAls pada masa pandemi Covid 19 di Rumah Sakit Pertamina Bintang Amin Bandar Lampung Tahun 2021

Metode: Jenis penelitian kuantitatif, rancangan Cross Sectional. Populasi dan sampel 110,1 responden, yang dibulatkan menjadi 111 responden, teknik sampling purposive sampling, analisa data menggunakan univariat dan bivariat menggunakan uji chi square.

Hasil : Beban kerja fisik perawat sebanyak 57 responden $(51,4 \%)$ mengalami beban kerja fisik tinggi. Beban kerja mental perawat sebanyak 61 responden $(55,0 \%)$ mengalami beban kerja mental tinggi. Upaya pencegahan HAls pada masa pandemi Covid 19 sebanyak 64 responden (57,7\%) dengan pencegahan hais baik. Hasil analisa menggunakan chi-square, didapat $P$-Value $=0,000$ sehingga $P$-Value $<a \quad(0,000<0,05)$ maka dapat disimpulkan terdapat hubungan beban kerja fisik perawat dengan upaya pencegahan HAls pada masa pandemi covid 19. Hasil analisa menggunakan chi-square, didapat $P$-Value $=0,015$ sehingga $P$ Value $<a(0,000<0,05)$ maka dapat disimpulkan terdapat hubungan beban kerja fisik mental perawat dengan upaya pencegahan HAls pada masa pandemi covid 19.

Saran : Rumah Sakit sebagai tempat pelayanan kesehatan, sebaiknya memperhatikan kesjahteraan perawat dengan cara memperbanyak tim medis, 
dan memperhatikan BOR guna mencegah terjadinya beban kerja fisik dan mental.

Kata Kunci: Beban Kerja Perawat, Upaya Pencegahan Hais, Pandemi Covid 19

\section{PENDAHULUAN}

Pada tanggal 20 Februari 2021 Indonesia mencatat penambahan jumlah kasus Covid 19 mencapai 1.271.353 orang, sembuh sebanyak 1.078 .840 orang, dan yang meninggal mencapai 34.316 orang. Di provinsi lampung sendiri pada tanggal 20 Februari kasus terkonfirmasi tercatat sebanyak 11.922 orang, sembuh sebanyak 10.195 orang, dan meninggal sebanyak 617 orang (Data Dinkes Lampung, 2021).

Infeksi terkait kesehatan, atau Healthcare Associated Infection (HAls), merupakan salah satu masalah kesehatan di negaranegara di dunia, termasuk Indonesia. Infeksi di Forum Asia Pacific Economic Council (APEC) atau Global Health Security Agent (GHSA). Padahal, terjadinya HAI dapat dicegah jika institusi medis secara sistematis menerapkan rencana PPI. Kewaspadaan standar harus memenuhi 11 komponen, salah satunya kebersihan jari tangan (Permenkes RI 2017).

Prevalensi HAls di rumah sakit di seluruh dunia telah mencapai 9\%, mempengaruhi sekitar 1,40 juta pasien rawat inap di rumah sakit di seluruh dunia dengan infeksi nosokomial. Menurut survei WHO, sekitar $8,70 \%$ dari 55 rumah sakit di 14 negara di Eropa, Timur Tengah, Asia Tenggara, dan Pasifik memiliki HAls. Prevalensi HAls adalah 11,80 dan $10 \%$, tertinggi di Mediterania timur dan Asia Tenggara, tetapi masing-masing 7,70\% dan 9\% di Eropa dan Pasifik barat (Kurniawati, Satyabakti dan Arbianti dan Hapsari 2018).
Prevalensi HAls di negaranegara berpenghasilan tinggi sekitar 3,5 sampai $12 \%$. Sementara itu, prevalensi di negara berpenghasilan rendah dan menengah sekitar 5.7 sampai $19,1 \%$, termasuk di Indonesia 7,1\% (Hasan, 2016). Angka kejadian infeksi nosokomial di rumah sakit di Indonesia masih sangat tinggi, angka infeksi diketahui masih $55,1 \%$ di rumah sakit umum dan 35,7\%, 4.444 di rumah sakit swasta. Di negara berkembang, termasuk Indonesia, rata-rata kejadian infeksi adalah 9,1 dengan variasi 6,1\% hingga 16,0\%. (Suroso 2014 dan Ratnawati 2018).

Di rumah sakit, perawat sangat berisiko terhadap kecelakaan dan penyakit akibat pekerjaan yang dilakukannya. Meskipun perawat sangat berisiko dalam pekerjaannya karena merupakan petugas kesehatan yang paling lama kontak dengan pasien, namun banyak perawat yang tidak menyadari risiko yang mengancamnya dan melupakan keselamatan dan kebersihan kerja (K3). Data WHO (2004): 35 juta petugas kesehatan, di antaranya 3 juta telah terpajan patogen darah (2 juta HBV, 900.000 HBC dan 170.000 HIV/AIDS). (Siregar, F.N 2020).

Meskipun memiliki kewajiban profesional untuk merawat pasien selama pandemi, banyak perawat khawatir tentang pekerjaan mereka dan dampaknya terhadap mereka. Isu utama adalah risiko penyakit menular, gelombang radio untuk keluarga, stigma di tempat kerja dan pembatasan kebebasan pribadi (Hope et al, 2011; Koh, Hegney, dan Drury, 
2012). Situasi konflik perawat selama penyakit menular merupakan masalah logistik terkait ketersediaan alat pelindung diri (APD). (Zhu, Y., Xie, J., Huang, F., dan Cao, L. 2020).

Perawat menghadapi berbagai kesulitan dalam bekerja, seperti beban kerja yang berlebihan, keperawatan yang buruk, citra perawat yang tidak stabil, motivasi kerja yang berkurang, dan mimpi buruk kerja. Jika ada keseimbangan antara jumlah rumah sakit dan beban perawat, kami akan memberikan layanan keperawatan yang berkualitas tinggi. Semakin tinggi aktivitas perawat dalam memberikan pelayanan kepada pasien mempengaruhi hasil pekerjaannya (Barahama, 2019; Zainaro et. al, 2020). Kualitas pelayanan rumah sakit dapat diukur dengan salah satu indikator kejadian infeksi nosokomial. (Nurseha 2013).

Berdasarkan hasil Prasurvey perbandingan beban kerja perawat di Rumah Sakit Pertamina Bintang Amin Bandar Lampung dan RSUD $d r$. A. Dadi Tjokrodipo dengan cara melakukan penyebaran kuesioner kepada 15 perawat di masingmasing Rumah Sakit. Pada RS. Pertamina Bintang Amin diperoleh hasil perawat mengalami beban kerja fisik sebesar 7 perawat $(46,6 \%)$ dengan skor nilai $27-54$, dan beban kerja mental sebesar 8 perawat $(53,3 \%)$ dengan skor nilai > 57. Sedangkan RSUD $d r$. A. Dadi Tjokrodipo diperoleh hasil perawat mengalami beban kerja fisik sebesar 5 perawat $(33,3 \%)$ dengan skor nilai 27-54, dan beban kerja mental sebesar 6 perawat $(40 \%)$ dengan skor nilai $>57$.

Beban kerja bisa ringan jika ada mahasiswa praktik dan keluarga pasien terlibat dalam mendukung proses pengobatan pasien. Jika beban kerja terlalu besar, ada risiko kinerja perawatan pasien perawat akan berkurang, dan dapat terjadi infeksi nosokomial (Zainaro et. al, 2021).

Berdasarkan data kejadian infeksi di Rumah Sakit Pertamina Bintang Amin Bandar Lampung 3 tahun terakhir didapat data sebagai berikut, pada tahun 2018 kejadian infeksi plebitis sebanyak 4,58\%, Infeksi Saluran Kemih 1,71\%, Ventilator-associated

pneumonia (VAP) $\quad 0,00 \%$, Infeksi aliran darah perifer (IADP) 0,53\%, Infeksi luka operasi (ILO) 0,91\%. Pada tahun 2019 kejadian infeksi plebitis sebanyak 0,27\%, Infeksi Saluran Kemih $0,14 \%$, Ventilator-associated

pneumonia (VAP) 0,00\%, Infeksi aliran darah perifer (IADP) 0,00\%, Infeksi luka operasi (ILO) 0,00 . pada tahun 2020 kejadian infeksi plebitis sebanyak $0,18 \%$, Infeksi Saluran Kemih 1,14\%, Ventilator-associated

pneumonia (VAP) 2,18\%, Infeksi aliran darah perifer (IADP) 0,00\%, Infeksi luka operasi (ILO) $0,00 \%$.

Berdasarkan data diatas dapat diketahui jika pada setiap tahun kejadian infeksi di Rumah Sakit Pertamina Bintang Amin Bandar Lampung mengalami kenaikan yang fluktuatif, akan tetapi pada tahun 2020, infeksi Ventilator-associated pneumonia (VAP) merupakan kejadian infeksi dengan persentase tertinggi.

\section{METODE PENELITIAN}

Penelitian ini berjenis kuantitatif, menggunankan rancangan Cross Sectional dimana pengumpulan data untuk variabel resiko/sebab (independent variable) dan variabel akibat (dependent variable) dilakukan dalam waktu yang bersama. Populasi dalam penelitian 
ini adalah seluruh perawat di Rumah

Sakit Pertamina Bintang Amin Bandar Lampung sebanyak 152 orang. Teknik sampling pada penelitian ini menggunakan purposive sampling. Analisa data univariat dan bivariat menggunakan uji C-Square.

HASIL PENELITIAN DAN PEMBAHASAN

Analisa Univariat

Tabel. 2

Distribusi Frekuensi Beban Kerja Fisik Perawat Di Rumah Sakit Pertamina Bintang Amin Bandar Lampung Tahun 2021

\begin{tabular}{|c|c|c|}
\hline Beban Kerja Fisik & Frekuensi & Persentase (\%) \\
\hline Tinggi & 57 & 51,4 \\
\hline Sedang & 54 & 48,6 \\
\hline Total & 111 & 100 \\
\hline
\end{tabular}

Berdasarkan tabel 2 diatas maka dapat di simpulkan bahwa beban kerja fisik perawat di Amin Bandar Lampung Tahun 2021, sebanyak 57 responden $(51,4 \%)$

mengalami beban kerja fisik tinggi, dan 54 responden $(48,6 \%)$ mengalami beban kerja fisik sedang.

Tabel. 3

Distribusi Frekuensi Beban Kerja Mental Perawat Di Rumah Sakit Pertamina Bintang Amin Bandar Lampung Tahun 2021

\begin{tabular}{|c|c|c|}
\hline Beban Kerja Mental & Frekuensi & $\begin{array}{c}\text { Persentase } \\
\text { (\%) }\end{array}$ \\
\hline Tinggi & 61 & 55,0 \\
\hline Sedang & 50 & 45,0 \\
\hline Total & 111 & 100 \\
\hline
\end{tabular}

Berdasarkan tabel 3 diatas maka dapat disimpulkan bahwa beban kerja mental perawat di Rumah Sakit Pertamina Bintang Amin Bandar Lampung Tahun 2021, sebanyak 61 responden $(55,0 \%)$ mengalami beban kerja mental tinggi, dan 50 responden $(45,0 \%)$ mengalami beban kerja mental sedang.

Tabel. 4

Distribusi Frekuensi Upaya Pencegahan HAls Pada Masa Pandemi Covid 19 Di Rumah Sakit Pertamina Bintang Amin Bandar Lampung Tahun 2021

\begin{tabular}{|c|c|c|}
\hline Pencegahan Hais & Frekuensi & $\begin{array}{c}\text { Persentase } \\
\text { (\%) }\end{array}$ \\
\hline Tidak Baik & 64 & 57,7 \\
\hline Baik & 47 & 42,3 \\
\hline Total & 111 & 100 \\
\hline
\end{tabular}


Berdasarkan tabel 4 diatas maka dapat disimpulkan bahwa upaya pencegahan HAls Pada saat Pandemi Covid 19 di Rumah Sakit Pertamina Amin Bandar Bandar
Lampung Tahun 2021, sebanyak 64 responden (57,7\%) dengan pencegahan HAls tidak baik dan sebanyak 47 responden $(42,3 \%)$ pencegahan HAls baik.

\section{Analisa Bivariat}

Tabel. 5

Hubungan Beban Kerja Fisik Perawat Dengan Upaya Pencegahan HAls Pada Masa Pandemi Covid 19 Di Rumah Sakit Pertamina Bintang Amin Bandar Lampung

\begin{tabular}{|c|c|c|c|c|c|c|c|c|}
\hline \multirow{3}{*}{$\begin{array}{c}\text { Beban } \\
\text { Kerja } \\
\text { Fisik }\end{array}$} & \multicolumn{4}{|c|}{ Pencegahan HAls } & \multirow{2}{*}{\multicolumn{2}{|c|}{ Total }} & \multirow{2}{*}{$\begin{array}{l}\text { P- } \\
\text { Val } \\
\text { ue }\end{array}$} & \multirow[t]{2}{*}{ OR } \\
\hline & \multicolumn{2}{|c|}{ Tidak Baik } & \multicolumn{2}{|c|}{ Baik } & & & & \\
\hline & $\mathbf{N}$ & $\%$ & $\mathbf{N}$ & $\%$ & $\mathbf{N}$ & $\%$ & & \\
\hline Tinggi & 51 & 45,9 & 6 & 5,4 & 57 & 51,4 & & 26,808 \\
\hline Sedang & 13 & 11,7 & 41 & 36,9 & 54 & 48,6 & 0,0 & $(9,371-$ \\
\hline Total & 64 & 57,7 & 47 & 42,3 & 111 & 100,0 & 00 & $76,689)$ \\
\hline
\end{tabular}

Berdasarkan tabel 5 diatas maka dapat disimpulkan bahwa dari 111 perawat, sebanyak 57 responden $(51,4 \%)$ menyatakan memiliki beban kerja fisik tinggi, dan sebanyak 51 responden $(45,9 \%)$ dengan pencagahan HAls tidak baik, 6 responden $(5,4 \%)$ dengan pencegahan HAls baik. Sebanyak 54 responden $(48,6 \%)$ menyatakan memiliki beban kerja fisik sedang, dan sebanyak 13 responden $(11,7 \%)$ dengan pencegahan HAls tidak baik, 41 responden $(36,9 \%)$ dengan pencegahan HAls baik.
Hasil analisa menggunakan chi-square, didapat $P$-Value $=0,000$ sehingga $P$-Value $<a \quad(0,000<0,05)$ maka dapat disimpulkan terdapat hubungan beban kerja fisik perawat dengan upaya pencegahan HAls Pada saat Pandemi Covid 19 di Rumah Sakit Pertamina Amin Bandar Bandar Lampung Tahun 2021, dengan nilai $\mathrm{OR}=26,808$ artinya perawat yang memiliki beban kerja fisik tinggi akan 26 kali beresiko memiliki penanganan HAls yang tidak baik.

Tabel. 6

Hubungan Beban Kerja Mental Perawat Dengan Upaya Pencegahan Hais Pada Masa Pandemi Covid 19 Di Rumah Sakit Pertamina Bintang Amin Bandar Lampung Tahun 2021

\begin{tabular}{|c|c|c|c|c|c|c|c|c|}
\hline \multirow{3}{*}{$\begin{array}{c}\text { Beban } \\
\text { Kerja } \\
\text { Mental }\end{array}$} & \multicolumn{4}{|c|}{ Pencegahan HAls } & \multicolumn{2}{|c|}{ Total } & \multirow{2}{*}{$\begin{array}{l}P \text { - } \\
\text { Value }\end{array}$} & \multirow[t]{2}{*}{ OR } \\
\hline & \multicolumn{2}{|c|}{ Tidak Baik } & \multicolumn{2}{|c|}{ Baik } & & & & \\
\hline & $N$ & $\%$ & $\mathbf{N}$ & $\%$ & $\mathbf{N}$ & $\%$ & & \\
\hline Tinggi & 42 & 37,8 & 19 & 17,1 & 61 & 55,0 & & 2,813 \\
\hline Sedang & 22 & 19,8 & 28 & 25,2 & 50 & 45,0 & 0,015 & $(1,292-$ \\
\hline Total & 64 & 57,7 & 47 & 42,3 & 111 & 100,0 & & $6,126)$ \\
\hline
\end{tabular}


Berdasarkan tabel 6 diatas maka dapat disimpulkan bahwa dari 111 perawat, sebanyak 61 responden $(55,0 \%)$ menyatakan memiliki beban kerja mental tinggi, dan sebanyak 42 responden $(37,8 \%)$ dengan pencegahan HAls tidak baik, 19 responden $(17,1 \%)$ dengan pencegahan HAls baik. Sebanyak 50 responden $(45,0 \%)$ menyatakan memiliki beban kerja mental sedang, dan sebanyak 22 responden $(19,8 \%)$ dengan pencegahan HAls tidak baik, 28 responden $(25,2 \%)$ dengan pencegahan HAls baik.

Hasil analisa menggunakan chi-square, didapat $P$-Value $=0,015$ sehingga $P$-Value $<a \quad(0,000<0,05)$ maka dapat kita simpulkan ada hubungan antara beban kerja mental perawat dengan upaya pencegahan HAls selama pandemi virus corona 19 di RS Pertamina Bintang Amin Bandar Lampung, 2021, dengan nilai OR $=2,813$ artinya perawat yang memiliki beban kerja mental tinggi akan 2 kali beresiko memiliki penanganan HAls yang tidak baik.

\section{PEMBAHASAN}

\section{Analisa Univariat}

\section{Distribusi Frekuensi Beban Kerja Fisik Perawat Di Rumah Sakit Pertamina Bintang Amin Bandar Lampung Tahun 2021}

Beban kerja fisik perawat di Rumah Sakit Pertamina Bintang Amin Bandar Lampung Tahun 2021, sebanyak 57 responden $(51,4 \%)$ merasakan beban kerja fisik tinggi, dan 54 responden $(48,6 \%)$ mengalami beban kerja fisik sedang.

Menurut Sugiono et all (2018) Kerja fisik adalah pekerjaan yang menggunakan energi fisik otot seseorang sebagai sumber energi. Jumlah kerja fisik menggunakan energi yang relatif besar dibandingkan dengan beban mental. Kerja fisik adalah Pekerjaan, yang membutuhkan energi fisik dari otot manusia sebagai sumber energi. Beban kerja fisik umumnya disebut sebagai "operasi manual", di mana pengembangan bisnis sepenuhnya tergantung pada orang, terlepas dari apakah kinerja kerja berfungsi pada sumber catu daya atau pengontrol tugas (kontrol). Konsumsi energi merupakan faktor dan parameter penting yang menunjukkan pentingnya beban kerja fisik. Ini bukan karena aktivitas fisik langsung, tetapi dengan aksi otak kita.

Menurut penelitian Dewi Kusumaningsih (2020) Hubungan Beban Kerja Fisik Dan Mental Perawat Dengan Penerapan Pasien Safety Pada Masa Pandemi Covid 19 Di Upt Puskesmas Rawat Inap Kabupaten Pesawaran. Hasil: Uji statistik beban kerja fisik chi-square, diperoleh $\mathrm{P}$ Value $=0,019$ sehingga $P$-Value $<$ a $(0,01<0,05)$ maka HO ditolak dengan nilai Oods Ratio 0.198.

Sesuai dengan penelitian Dewi Kusumaningih (2020) Hasil penelitian yang didapat kebanyakan perawat mengalami terlalu banyak pekerjaan. Hal-hal yang harus dilakukan untuk menjaga keamanan pasien sering dilakukan, tetapi langkahlangkah yang berlaku tidak akan diikuti karena aktivitas kerja fisik yang melebihi kekuatan perawat dapat mengurangi produktivitas tenaga kerja..

Menurut pendapat peneliti aktivitas perawat pada satu waktu terkadang berbeda disebabkan karena beban tugas yang sangat bervariasi dan juga dipengaruhi oleh jumlah pasien 
yang berkunjung. Perbedaan aktivitas kerja ini menyebabkan terjadinya perbedaan beban kerja fisik yang pada akhirnya berdampak pada terjadinya kelelahan kerja.

2. Distribusi Frekuensi Beban Kerja Mental Perawat Di Rumah Sakit Pertamina Bintang Amin Bandar Lampung Tahun 2021

Beban kerja mental perawat di Rumah Sakit Pertamina Bintang Amin Bandar Lampung Tahun 2021, sebanyak 61 responden $(55,0 \%)$ merasakan beban kerja mental berat, dan 50 responden $(45,0 \%)$ merasakan beban kerja mental sedang.

Menurut teori Mutia (2014; Diniaty, 2018) Beban kerja mental merupakan kondisi kerja yang mengharuskan otak memproses informasi. Mental Walk melibatkan fungsi otak yang sempit dan pemrosesan informasi. Fungsi otak konsensual adalah proses berpikir yang membutuhkan kreativitas, seperti membangun mesin, menulis rencana produksi, dan menulis laporan pembelajaran dari file. Beban kerja mental adalah perbedaan antara tuntutan beban kerja suatu tugas dan kapasitas beban mental terbesar seseorang dalam keadaan motivasi.

Sejalan dengan penelitian Dewi Kusumaningsih (2020) Hubungan Beban Kerja Fisik Dan Mental Perawat Dengan Penerapan Pasien Safety Pada Masa Pandemi Covid 19 Di Upt Puskesmas Rawat Inap Kabupaten Pesawaran. Hasil: Uji statistik beban kerja mental menggunakan chi-square, didapat Hasil: Statistik uji stres mental menggunakan analisis chisquare, diperoleh $\mathrm{P}$-Value = 0,364 , sehingga $P$-Value $<a$
$(0,364>0,05)$ maka $\mathrm{Ha}$ ditolak dengan nilai Oods Ratio 1.857

Sejalan dengan pendapat yang dikemukan oleh (Selye) (1950; Hidayat, 2011) Stres adalah reaksi tubuh yang tidak spesifik terhadap kebutuhan dan beban tubuh. Stres dapat terjadi ketika seseorang tidak mampu mengatasi tugas yang diberikan ketika menjalani beban atau tugas yang berat, dan tubuh tidak responsif terhadap tugas tersebut dan dapat menjadi stres.

Menurut pendapat penelitian, pekerjaan perawat adalah sangat berat. Di sisi lain, perawat perlu memenuhi kewajiban mereka mengenai kelangsungan hidup pasien perawatan mereka. Situasi seperti dapat menyebabkan beban kerja tambahan dan penindasan pada perawat, mengakibatkan kinerja yang buruk bagi perawat dan secara tidak langsung memiliki dampak yang signifikan organisasi tempat mereka bekerja. Beban mungkin terlalu berat atau terlalu ringan dapat menyebabkan cacat yang berhubungan dengan pekerjaan dan penyakit.

3. Distribusi Frekuensi Upaya Pencegahan HAls Pada Masa Pandemi Covid 19 Di Rumah Sakit Pertamina Bintang Amin Bandar Lampung Tahun 2021

Upaya pencegahan HAls selama pandemi Covid 19 di RS Pertamina Bintang Amin Bandar Lampung tahun 2021, sebanyak 64 responden (57,7\%) dengan pencegahan hais tidak baik dan sebanyak 47 responden $(42,3 \%)$ pencegahan hais baik.

Menurut Menteri Kesehatan RI (2017), infeksi terkait perawatan kesehatan atau (Healthcare Associated Infections) HAls adalah infeksi 
yang terjadi tidak hanya di rumah sakit tetapi juga di tatanan pelayanan lainnya. Infeksi tidak hanya menyebar ke pasien, tetapi dapat juga menular ke petugas kesehatan yang terinfeksi dan wisatawan di fasilitas kesehatan juga dapat ditularkan.

Sejalan dengan penelitian yang dilakukan oleh Krisnata (2016) Faktor - Faktor Yang Berhubungan Dengan Praktik Universal Precautions Pada Perawat Dalam Upaya Pencegahan Risiko Healthcare Associated Infections (Hais) Di Ruang Rawat Inap Rsud Tugurejo Semarang. Hasil penelitian faktor-faktor yang berkaitan dengan praktik tindakan pencegahan universal adalah pengetahuan tentang infeksi nosokomial dan upaya pencegahan $(p=0,014)$.

Pada pengisian kuisioner penelitian ini, didapat hasil penggunaan handscone yang berbeda pada setiap pasien merupakan pencegahan HAls, yang sering diabaikan oleh perawat. Ketersediaan alat kesehatan seperti handscone yang bersih dan tidak dialakukan sercara bergantian dapat menimbulkan penyakit baru bagi pasien lain. Ketersediaan dan keadaan siap pakai fasilitas pada waktu yang tetap berupa sumber daya manusia, barang, modal, anggaran, dll. Hal ini menunjukkan bahwa fasilitas yang tersedia harus segera tersedia dan belum rusak dan belum kadaluarsa serta tidak kekurangan persediaan. Tanpa fasilitas yang tepat, kemampuan yang mumpuni sekalipun tidak dapat meningkatkan efisiensi, efisiensi, dan produktivitas operasional.

Menurut pendapat Direktur P2 MPL (2010), sumber daya yang dibutuhkan tenaga kesehatan dalam praktik pencegahan dan pengendalian infeksi di tempat kerja adalah sarana dan prasarana toilet, dan ketersediaan alat pelindung diri (APD) desinfektan dan pengelolaan disinfektan dan benda tajam serta peralatan penanganan limbah medis dan non medis.

Menurut pendapat peneliti Healthcare Associated Infections (HAls) terjadi pada pasien yang dirawat di rumah sakit tanpa gejala klinis infeksi karena radioaktivitas organisme patogen, dan pasien pada saat masuk rumah sakit dan dari sakit. tanda-tanda klinis infeksi Infeksi muncul minimal 3x24 jam setelah dimulainya pengobatan, dan infeksi tidak memiliki sisa infeksi.

\section{Analisa Bivariat}

1. Hubungan Beban Kerja Fisik Perawat Dengan Upaya Pencegahan HAls Pada Masa Pandemi Covid 19 Di Rumah Sakit Pertamina Bintang Amin Bandar Lampung Tahun 2021

Dari 111 perawat, sebanyak 57 responden $(51,4 \%)$ menyatakan memiliki beban kerja fisik tinggi, dan sebanyak 51 responden $(45,9 \%)$ dengan pencegahan HAls tidak baik, 6 responden $(5,4 \%)$ dengan pencegahan HAls baik. Sebanyak 54 responden (48,6\%) menyatakan memiliki beban kerja fisik sedang, dan sebanyak 13 responden $(11,7 \%)$ dengan pencegahan HAls tidak baik, 41 responden $(36,9 \%)$ dengan pencegahan HAls baik.

Hasil analisa menggunakan analisis chi-square, diperoleh hasil ' $P$-Value $=0,000$ sehingga $P$-Value $<a \quad(0,000<0,05)$ Dapat disimpulkan bahwa ada hubungan antara beban kerja fisik perawat dengan upaya 
pencegahan HAls pada masa pandemi Covid 19 di RS Pertamina Bintang Amin Bandar Lampung tahun 2021., dengan nilai OR = 26,808 artinya perawat yang memiliki beban kerja fisik tinggi akan 26 kali beresiko memiliki penanganan HAls yang tidak baik.

Sejalan dengan teori yang dikemukakan oleh Sugiono et al (2018), beban kerja yang sebenarnya adalah Bekerja, yang membutuhkan kekuatan fisik otot seseorang sebagai sumber energi. Beban kerja nyata menggunakan energi yang relatif lebih banyak dibandingkan dengan beban kerja mental. Kerja nyata atau kerja nyata adalah kerja yang membutuhkan tenaga fisik otot manusia sebagai sumber tenaga atau tenaga. Beban kerja aktual biasanya disebut sebagai "manipulasi manual" dan kinerja tugas sepenuhnya bergantung pada manusia, baik bertindak sebagai sumber daya (daya) atau pengontrol tugas (kontrol). Konsumsi energi adalah faktor yang paling penting dan parameter bobot beban kerja fisik. Ini bukan karena aktivitas fisik langsung, tetapi dengan aksi otak kita.

Sejalan dengan teori yang dikemukakan oleh Permenkes (2017), Penyakit menular yang berhubungan dengan pelayanan kesehatan. Healthcare Associated Infections (HAl) adalah penyakit infeksi yang terjadi tidak hanya di rumah sakit tetapi juga di fasilitas pelayanan lainnya. Hal ini tidak terbatas pada infeksi pasien, dapat menginfeksi tenaga medis dan wisatawan yang terinfeksi di lingkungan fasilitas kesehatan.

Sejalan dengan penelitian yang dilakukan oleh Krisnata (2016) Faktor - Faktor Yang Berhubungan Dengan Praktik Universal Precautions Pada Perawat Dalam Upaya Pencegahan Risiko
Healthcare Associated Infections (Hais) Di Ruang Rawat Inap Rsud Tugurejo Semarang. Hasil penelitian faktor-faktor yang berkaitan dengan praktik tindakan pencegahan universal adalah pengetahuan tentang infeksi nosokomial dan upaya pencegahan $(p=0,014)$.

Menurut pendapat peneliti bahwa beban kerja tinggi dengan pencegahan HAls tidak baik, hal ini disebabkan karena perawat mengalami kelelahan yang meliputi kelelahan otot, fisik yang berdampak pada penurunan semangat bekerja. beban kerja tinggi dengan pencegahan HAls baik, hal ini dapat disebabkan karena tingginya rasa tanggung jawab yang dimiliki perawat, serta semangat yang positif dimiliki oleh perawat yang berdampak pada perilaku positif pencegahan HAls. beban kerja fisik sedang dengan pencegahan HAls tidak baik, hal ini disebabkan Pekerjaan fisik yang melebihi kapasitas perawat dapat mengurangi produktivitasnya dalam pekerjaan sehingga langkah-langkah tersebut akan diambil untuk memastikan bahwa keselamatan pasien sering dilakukan, tetapi tidak sesuai dengan prosedur yang berlaku.

Beban kerja fisik sedang dengan pencegahan HAls baik, hal ini dapat disebabkan Namun, infeksi yang terjadi di rumah sakit tidak dapat dikontrol, tetapi juga dapat dicegah dengan menciptakan sesuai dengan prosedur dan kebijakan yang berlaku. Langkah-langkah untuk mengurangi atau meminimalkan infeksi tingkat infeksi dalam hal layanan kesehatan, program implementasi PPI, termasuk pertukaran isolasi, yang terdiri dari kewaspadaan standar dan kewaspadaan transmisi. beban kerja fisik terjadi akibat tidak seimbangnya antara jumlah perawat dengan jumlah pasien yang 
mendapat perawatan sehingga menimbulkan beban kerja yang berat. Hal ini menyatakan jika seluruh perawat memiliki beban kerja fisik yang sangat berat untuk menerapkan protokol kesehatan dimasa pandemi ini, guna menurunkan dampak HAls.

2. Hubungan Beban Kerja Mental Perawat Dengan Upaya Pencegahan Hais Pada Masa Pandemi Covid 19 Di Rumah Sakit Pertamina Bintang Amin Bandar Lampung Tahun 2021

Dari 111 perawat, sebanyak 61 responden $(55,0 \%)$ menyatakan memiliki beban kerja mental tinggi, dan sebanyak 42 responden $(37,8 \%)$ dengan pencegahan HAls tidak baik, 19 responden $(17,1 \%)$ dengan pencegahan HAls baik. Sebanyak 50 responden $(45,0 \%)$ menyatakan memiliki beban kerja mental sedang, dan sebanyak 22 responden $(19,8 \%)$ dengan pencegahan HAls tidak baik, 28 responden $(25,2 \%)$ dengan pencegahan HAls baik.

Hasil analisa menggunakan chisquare, diperoleh $P$-Value $=0,015$ sehingga $P$-Value $<a \quad(0,000<0,05)$ maka disimpulkan ada hubungan beban kerja mental perawat dengan upaya pencegahan hais pada masa pandemi covid 19 di Rumah Sakit Pertamina Bintang Amin Bandar Lampung Tahun 2021, dengan nilai $\mathrm{OR}=2,813$ artinya perawat yang memiliki beban kerja mental tinggi akan 2 kali beresiko memiliki penanganan HAls yang tidak baik.

Sejalan dengan teori yang dikemukakan oleh Mutia, 2014; Diniaty, (2018) Mental Workload adalah deskripsi kerja, dalam informasi yang masih perlu diproses di otak, harus diproses dalam latar belakang ini. Pekerjaan intelektual termasuk pekerjaan otak dalam pikiran sempit dan informasi pemrosesan. Pekerjaan otak dalam perasaan dekat adalah proses berpikir yang membutuhkan kreativitas, misalnya mesin, menciptakan rencana produksi, membuat file dan menulis laporan. Beban kerja mental adalah perbedaan antara persyaratan beban kerja tugas dengan kapasitas maksimum beban spiritual seseorang pada kondisi termotivasi.

Sejalan dengan teori yang dikemukakan oleh Permenkes RI (2017) Healthcare Associated Infectious Diseases atau Health Associated Infections (HAls) adalah infeksi yang terjadi tidak hanya di rumah sakit tetapi juga di tempat pelayanan lainnya. Infeksi tidak hanya menyebar ke pasien, tetapi juga ketenaga medis dan pengunjung yang terinfeksi saat berada di fasilitas medis.

Sesuai dengan penelitian yang dilakukan oleh Dewi Kusumaningsih (2020) Hubungan Beban Kerja Fisik Dan Mental Perawat Dengan Penerapan Pasien Safety Pada Masa Pandemi Covid 19 Di Upt Puskesmas Rawat Inap Kabupaten Pesawaran. Hasil: Uji statistik dari beban kerja fisik chi-square, diperoleh P-Vauel= 0,019 sehingga P-Value $<a$ $(0,01<0.05)$ maka Ho ditolak dengan nilai Oods Ratio 0,198. Kemudian uji statistic beban kerja mental menggunakan analisis Chi-square, diperoleh <a $(0,364>0,05)$ maka $\mathrm{Ha}$ ditolak dengan nilai rasio OOD 1.857 .

Menurut pendapat peneliti bahwa beban kerja mental tinggi dengan pencegahan HAls baik, hal ini dapat disebabkan konsumen pendidikan, yaitu tingkat pendidikan masyarakat semakin tinggi, oleh karena itu perawat harus profesional, atau dengan kata lain perawat lebih dibutuhkan satu tingkat lebih tinggi dari tingkat pendidikan masyarakat lebih rendah daripada di masyarakat.

Selain itu, semua perawat perlu mengikuti kemajuan ilmu pengetahuan dan teknologi 
khususnya kemajuan ilmu pengetahuan dan teknologi termasuk bahasa, karena jika tidak dapat mengikuti maka otomatis tidak dapat memasuki pasar kerja. Artinya semua organisasi pelayanan memilih perawat dengan kemampuan internasional.

Selain pendidikan responden, faktor lain berdasarkan karakteristik responden adalah umur panjang adalah proses pembentukan pengetahuan-pengetahuan dan keterampilan metode kerja sebagai karyawan berpartisipasi dalam pelaksanaan tugas pekerjaan, sehingga dengan masa kerja yang panjang dapat meningkatkan teknik dan metode kerja dapat ditingkatkan untuk mengurangi tingkat stres bagi karyawan dan pekerja. Jam kerja yang lebih lama dapat mempengaruhi persepsi perawat, karena mereka mendapatkan pemahaman dan pengetahuan yang lebih tentang manfaat perawat dan lebih banyak pengetahuan tentang dokumentasi keperawatan. Efek dari kerja yang berlebihan tidak hanya menimbulkan kelelahan fisik, tetapi juga kerja mental. Seperti sekarang ini, dalam situasi Covid19 perawat harus melakukan pekerjaan yang berat, dan karena pelayanan yang diberikan, ketidakpuasan pasien dan ketidakpuasan penyakit dapat muncul berdampingan dan menyebabkan kelelahan perawat meningkat. Kesombongan dari pasien, yang cenderung membuat perawat merasa lelah secara fisik, mental dan spiritual, tidak hanya di pihak pasien, tetapi juga di pihak dokter yang cenderung menuntut atau mengeluh tentang banyak hal. , keluarga pasien, rekan kerja yang tidak antri, dll.

Masalah lain yang sering dialami perawat adalah ketidakpuasan pasien terhadap dokter, seringnya perawat kasar pulang terlambat, kinerja manajemen pelayanan yang tertunda. Juga, tergantung pada jumlah pasien yang berobat, ruangan yang disediakan mungkin tidak memenuhi kapasitas pasien yang ada.

Hal ini memungkinkan perawat mengalami kelelahan fisik, emosional dan mental. Kehadiran beberapa masalah dapat memberitahu Anda bagaimana seorang perawat memiliki beban, apakah lingkungan kerja perawat itu baik atau buruk. Situasi dan situasi rumah sakit merupakan faktor penting bagi perawat, karena berbagai hal yang akan dihadapi perawat dalam menjalankan tugasnya, dan rumah sakit akan memungkinkan perawat memenuhi tugas dan tanggung jawabnya setiap hari.

\section{KESIMPULAN}

1. Beban kerja fisik perawat di Rumah Sakit Pertamina Bintang Amin Bandar Lampung Tahun 2021, sebanyak 57 responden $(51,4 \%)$ mengalami beban kerja fisik tinggi.

2. Beban kerja mental perawat di Rumah Sakit Pertamina Bintang Amin Bandar Lampung Tahun 2021, sebanyak 61 responden $(55,0 \%)$ mengalami beban kerja mental tinggi.

3. Upaya pencegahan HAl pada masa pandemi Covid 19 di RS Pertamina Bintang Amin Bandar Lampung tahun 2021.sebanyak 64 responden (57,7\%) dengan pencegahan hais tidak baik

4. Hasil analisa menggunakan analisis chi-square, diperoleh $P$ Value $=0,000$ sehingga $P$-Value $<a \quad(0,000<0,05)$ maka dapat disimpulkan ada hubungan beban kerja fisik perawat dengan upaya pencegahan HAls pada masa pandemi covid 19 di Rumah Sakit Pertamina Bintang Amin Bandar Lampung Tahun 2021 
5. Hasil analisa menggunakan analisis chi-square, diperoleh $P$ Value $=0,015$ sehingga $P$-Value $<a \quad(0,000<0,05)$ maka dapat disimpulkan ada hubungan beban kerja fisik mental perawat dengan upaya pencegahan HAls pada masa pandemi covid 19 di Rumah Sakit Pertamina Bintang Amin Bandar Lampung Tahun 2021

Saran

1. Bagi Rumah Sakit Pertamina Bintang Amin Bandar Lampung

a. Diperlukan untuk menjaga kondisi dan lingkungan kerja, sehingga stres kerja dapat dikelola dengan roti ringan masih oleh perawat, sehingga jasa perawat tetap optimal. Diharapkan bagi pihak Rumah Sakit Bintang Amin

b. Diharapkan bagi pihak Rumah Sakit Bintang Amin, Rumah Sakit sebagai tempat pelayanan kesehatan, sebaiknya memperhatikan kesejahteraan perawat dengan cara memperbanyak tim medis, dan memperhatikan BOR guna mencegah terjadinya beban kerja fisik dan mental.

menciptakan lingkungan kerja antara perawat yang kondusif untuk kenyamanan dalam bekerja, melakukan rolling keruangan lain atau tukar patner dines.

c. serta menyiapkan alat medis berupa APD (Alat Pelindung Diri) dan handscoon merupakan alat kesehatan yang sangat sering digunakan untuk tindakan ke pasien, dan mencegah terjadinya penggunaan handscoon secara bergantian untuk beberapa pasien.

2. Bagi Ilmu Pengetahuan

Harapannya bahwa hasil penelitian ini dapat digunakan sebagai pembacaan atau referensi dalam studi penelitian atau sebagai bahan referensi untuk konsultasi bagi perawat konseling tentang stres fisik dan mental untuk pencegahan HAls, yang selanjutnya dapat dijadikan sebagai titik tolak. data untuk mengelola mutu pelayanan medis.

3. Bagi Peneliti Selanjutnya

Harapannya bahwa hasil penelitian ini dapat menjadi bahan pustaka bagi peneliti selanjutnya dan peneliti selanjutnya untuk menganalisis karakteristik responden, serta faktor-faktor lain yang mempengaruhi pencegahan infeksi HAls.

\section{DAFTAR PUSTAKA}

Al'amri (2017). Analisis Implementasi Pencegahan Dan Pengendalian Infeksi Di Rumah Sakit Umum Anutapura PaluSulawesi Tengah. Program Pascasarjana Universitas Hasanuddin Makassar 2017

Arikunto, S. (2010). Metode peneltian. Jakarta: Rineka Cipta.

Arini, T. (2018). Budaya Keselamatan Pasien Berbasis Pemberdayaan Struktural dengan Kepuasan Kerja Perawat (Doctoral dissertation, Universitas Airlangga).

Barahama, Kifly Franco (2019). Hubungan Beban kerja Dengan kepuasan Kerja Perawat Di Ruangan perawatan Dewasa Rsu Gmim Pancran Kasih Manado. E-Journal Keperawatan (eKp) Volume 7 Nomor 1, Februari 2019. Ejournal.unsrat.ac.id/in dex.php /jkp/a rticle. Diakses 21 Desember 2019

Data Dinkes Lampung. (2021) Informasi Covid 19

Depkes. (2011). Pedoman ManajerialPencegahan dan 
Pengendalian Infeksidi Rumah Sakit dan FasilitasPelayanan Kesehatan Lainnya.

Hasan A., Sularmo (2016) Prevalensi Healthcare Associated Infections (Hais) Di Rumah Sakit Umum Di Kota Bandar Lampung.

Hapsari. (2018). Pengetahuan Petugas Surveilans Tentang Identifikasi HealthcareAssociated Infections Di Surabaya

Isnainy, U. C. A. S., Furqoni, P. D., Ariyanti, L., \& Asdi, L. S. (2019). Hubungan Beban Kerja, Budaya Kerja Dan Lama Kerja Terhadap Stres Kerja Perawat Di Ruang Irna lii Rumah Sakit Umum Daerah Dr. H. Abdul Moeloek Provinsi Lampung. Malahayati Nursing Journal, 1(1).

Kasmarani, M. K. (2012). Pengaruh beban kerja fisik dan mental terhadap stres kerja pada perawat di Instalasi Gawat Darurat (IGD) RSUD Cianjur. Jurnal Kesehatan Masyarakat Universitas Diponegoro, 1(2), 18807.

Kemenkes RI (2020). Pedoman Pencegahan Dan Pengendalian Coronavirus Disease (Covid 19). Kemenkes RI 0-115.

Khoirudin, P., Zainaro, M. A., \& Andoko, A. (2021). Pengetahuan dan beban kerja perawat dengan penerapan kewaspadaan standar di RSUD Dr. A. Dadi Tjokrodipo Bandar Lampung. Holistik Jurnal Kesehatan, 15(3), 499-506.

Krisnata, A. (2016). Faktor-Faktor yang Berhubungan dengan Praktik Universal Precautions pada Perawat dalam Upaya Pencegahan Risiko Healthcare Associated Infections (HAls) di Ruang Rawat Inap RSUD Tugurejo Semarang (Doctoral dissertation, Universitas Negeri Semarang).

Kurniadi, Anwar. (2013). Manajemen Keperawatan Dan Prospektifnya.Jakarta

Fakultas

Kedokteran Universitas Indonesia.

Kusumaningsih, D. (2020). Hubungan Beban Kerja Fisik Dan Mental Perawat Dengan Penerapan Pasien Safety Pada Masa Pandemi Covid 19 Di Upt Puskesmas Rawat Inap Kabupaten

Pesawaran. Indonesian Journal of Health Development, 2(2), 108-118.

Madjid, T., \& Wibowo, A. (2019). Analisis Penerapan Program Pencegahan dan Pengendalian Infeksi di Ruang Rawat Inap RSUD Tebet Tahun 2017. Jurnal Administrasi Rumah Sakit Indonesia, 4(1).

Mutia. (2014; Diniaty, D. (2018). Analisis Beban Kerja Mental Operator Lantai Produksi Pabrik Kelapa Sawit dengan Metode NASA-TLX di PT. Bina Pratama Sakato Jaya, Dharmasraya. Jurnal Teknik Industri: Jurnal Hasil Penelitian dan Karya Ilmiah dalam Bidang Teknik Industri, 4(1), 1-6.

Notoatmodjo, S. (2018). Metodologi Penelitian Kesehatan. Jakarta: PT Rineka. Cipta.

Nursalam. (2018). 5 Manajemen Keperawatan. 5th ed. Jakarta: Salemba Medika

Nurseha, Djaafar (2013). Pengembangan Tindakan Pencegahan Infeksi Nosokomial Oleh Perawat Di Rumah Sakit Berbasis Health Belief Model. Jurnal Ners Vol. 8 No. 1 April 2013: 64-71.

PDPI. (2020). Pneumonia Covid19Diagnosis \& PenatalaksanaanDi Indonesia. ISBN: 978-623-92964-0-7 
Permenkes RI. (2017). Pedoman Pencegahan Dan Pengendalian Infeksi Di Fasilitas Pelayanan Kesehatan. Peraturan Menteri Kesehatan Republik Indonesia Nomor 27 Tahun 2017

Purba, Y. S. (2015). Hubungan Beban Kerja Mental Dan Peerilaku Perawat Pelaksana Dengan Keselamatan Pasien. Jurnal Impuls Universitas Binawan, 1(2), 5965.

Risqiansyah, M. Z. A., Hanurawan, F., \& Setiyowati, N. (2017). Hubungan Antara Beban Kerja Fisik Dan Beban Kerja Mental Berbasis Ergonomi Terhadap Tingkat Kejenuhan Kerja Pada Karyawan PT Jasa Marga(Persero)Tbk Cabang Surabaya Gempol.Jurnal Sains Psikologi, 6(1), 37-42.

Runtu, V. V., Pondaag, L., \& Hamel, R. (2018). Hubungan Beban Kerja Fisik dengan Stres Kerja Perawat Diruang Instalasi Rawat Inap Rumah Sakit Umum GMIM Pancaran Kasih Manado. Jurnal Keperawatan, 6(1).

Suroso. (2014; Ratnawati, L. Y., Sulistiyani, S., Rohmawati, N., Antika, R. B., Wirjatmadi, B., \& Adriani, M. Zinc Status and Cadmium Exposure in Stunted Children Aged from 24 to 59 Months: A Cross Sectional Study.

Siregar, F. N. (2020). Pelaksanaan Konsep Dasar Keselamatan Dan Kesehatan Kerja (K3) Di Rumah Sakit.

Sugiono., Putro, W. W\&Sari, S.I.K.(2018). Ergonomi Untuk Pemula: $\quad$ Prinsip Dasar\& Aplikasinya.Malang: UB Press.

Sugiyono. (2015). Metode Penelitian Kuantitatif, Kualitatif, dan R\&D. Bandung: Alfabeta.

Wicaksono (2015). "faktor-faktor yang berhubungan dengan pencegahan infeksi

nosokomial oleh perawat di instalasi rawat inap rumah sakit muhammadiyah palembang. sekolah tinggi ilmu kesehatan: Muhammadiyah palembang.

Yanti, D.E.P, dkk. (2020). Gambaran Motivasi Bekerja Perawat Dalam Masa Pandemi Coronavirus Disease (Covid19) Di Bali.Community of Publishing In Nursing (COPING), p-ISSN 2303-1298, e-ISSN 2715-1980.

Zainaro, M. A. (2021). The Leadership and Motivation on Inpatient Compliance in Preventing the Risk of Patients Falling. Psychology and Education Journal, 58(2), 241253.

Zainaro, M. A., \& Laila, S. A. (2020). Hubungan Motivasi Dan Sikap dengan Kepatuhan Perawat Dalam Pelaksanaan Hand Hygiene Di Ruang Rawat Inap Rsud Dr. A. Dadi Tjokrodipo Kota Bandar Lampung. Malahayati Nursing Journal, 2(1), 68-82.

Zainaro, M. A., \& Nurhidayat, M. (2020). Pengaruh kinerja petugas kesehatan pada tingkat kepuasan pasien. Holistik Jurnal Kesehatan, 14(2), 187-194.

Zainaro, M. A., Ridwan, R., \& Isnainy, U. C. A. S. (2021). Motivation and Workload of Nurses with Nurse Performance in Handling Events of Corona Virus (Covid19). Jurnal Aisyah: Jurnal Ilmu Kesehatan, 6(4), 673-680.

Zhu, Y., Xie, J., Huang, F., \& Cao, L. (2020). Association between short-term exposure to air pollution and COVID-19 infection: Evidence from China. Science of the total environment, 727, 138704. 